\title{
ANALYSIS OF ACCOUNTING BEHAVIOR OF ACCOUNTS RECEIVABLES IN THE RIGHT DECISION TAKING FOR BUSINESS DEVELOPMENT IN PT. S.S
}

\author{
Jeane Christine Lasut, Jufry Rompas, Decire D. Wagiu \\ Department Of Accounting, Polytechnic of Manado Country
}

\author{
Agnes J.E. Wakkary \\ Department Of Mechanical Engineering, Polytechnic of Manado Country \\ DOI: 10.31364/SCIRJ/v7.i11.2019.P1119725 \\ http://dx.doi.org/10.31364/SCIRJ/v7.i11.2019.P1119725
}

\begin{abstract}
The purpose of this research is to determine the accounting behavior of accounts receivable in order to make the right decision, for business development at PT. S.S in Manado. Receivables are claims arising from the sale of merchandise and services on credit, which can represent a large portion of a company's liquid assets. The research method used, namely with a qualitative descriptive approach, data obtained through observation, interviews, and literature study. The results showed that PT SS had 58 Business Partner Companies in 2018 with a percentage of health conditions, namely; current 87.94\%, under special supervision 6.9\%, non-current 1.72\%, doubtful 1.72\%, loss of 1, 72\%, and 24 Business Partner Companies, from 2019 to April with a percentage of health conditions, i.e. 100\% current. Trade receivables that occurred at PT S.S originated from the handover of capital of PT. S.S to the Business Partner Company, and from each Company the Business Partner will pay installments each month according to the ceiling, and the period of time that has been determined.
\end{abstract}

Keywords: Accounts Receivables, Accounting Behavior

\section{INTRODUCTION}

Currently Indonesia has experienced globalization in the economic field. This can be seen by the large number of emerging companies, originating from within and outside the country. These companies also have the same goal, which is to seek maximum profit. This will certainly lead to very fierce competition between these companies, so companies that are engaged in the same field, of course, find the right strategy to improve company performance. Each company basically runs its business through the sale of goods or services.

The sale of goods or services will generate income for the company. Sales are made by a company, generally done in two ways, namely cash sales and credit sales. Sales in cash generally will not cause significant problems for the company, while sales on credit will cause receivables, and the risk of payment for the company. Receivables are an important process, which can show a large part of a company's liquid assets. Receivables are considered very important because it is one of the components in the balance sheet, so accuracy in managing receivables is very influential on its valuation obligations in the financial statements. Proper accounting of accounts receivable, can have an important effect on financial statements, and appropriate Financial Accounting Standards, are very important in presenting financial reports because accounting standards provide information to users of financial statements about financial position, results of operations, and matters relating to company. When a company sells goods or services on credit, the company will recognize the receivables and be entitled to cash receipts in the future. In other words, receivables arise when companies provide loans to other companies or individuals. Companies in providing credit services, usually will set payment terms that are usually strict.

Strict conditions, for example, within the payment deadline, the imposition of fines is imposed on late payment receivables. Recording and recognition of the company regarding accounts receivables must be done carefully and reliably so as not to cause recording errors that can ultimately lead to large losses or the emergence of uncollectible receivables for the company. PT S. S is one of the companies engaged in capital financing. In general, this investment is carried out in the form of a cash handover to a business partner company that raises accounts receivable within a certain period. PT. S.S is one of the various types of companies that rely on receivables in running their business. In the economic world, the capital of PT. S.S is very important in helping many companies and individuals to develop their businesses in order to become more developed. Equity participation conducted by PT. S.S is mostly carried out on Micro, Small and Medium Enterprises. PT S.S which is doing a lot of daily activities through capital surrender transactions of PT. S.S, it is very necessary to handle the receivables to be managed properly and in accordance with applicable financial accounting standards, especially for accounts receivable. The problem in this 
research is that there are still business partner companies that have not followed the provisions in returning receivables in accordance with the agreement and the terms agreed upon in the binding agreement. Therefore, control over the accounting treatment of accounts receivable at PT. S.S is expected to produce accurate, reliable and relevant information about accounts receivables for decision making for company management and for business development and to safeguard company assets, especially in accounts receivables.

By looking at the importance of accounting treatment for accounts receivable in every company, especially companies that sell credit, it allows researchers to analyze the accounting treatment of accounts receivable at PT SS, is it appropriate and in accordance with financial accounting standards in order to make the right decision for business development . Based on the description above, the researcher is interested in conducting research with the title "Analysis of Accounting Behavior of Accounts Receivables In The Right Decision Taking for Business Development In PT. S.S "

\section{RESEARCH METHODS}

In this research, researchers used a qualitative descriptive method. Mukhtar (2013: 10) descriptive qualitative research method is a method used by researchers to find knowledge or theory of research at one particular time

\subsection{Data Source}

In this research, the data used by researchers include:

1. Primary data, in this case the researcher will make direct observations to the field at PT. S.S through direct interviews with parties related to accounts receivable, namely the accounting department. The data that will be used is the company's financial data that is used to control the company's financial condition.

2. Secondary data, is data obtained from data collection techniques that support primary data. In this research, obtained from observations made by the author as well as from literature studies. The data obtained by researchers directly from the company, namely PT. S.S is in the form of a data list of business partner companies, and a list of credit cards and other supporting data that are relevant to the problem in this research.

\subsection{Data Collection Technique}

To obtain the best information with the assumption that the target in the study is achieved, the authors conduct research directly to the object of research by:

2.2.1. Observation, the researcher is directly involved in the activity of finding the required data. The purpose of observation is to obtain various concrete data directly in the field.

2.2.2. Interviews, in qualitative research, are the main data collection methods. An interview is a conversation with a specific purpose. Interviews are used as data collection techniques, if researchers want to do a preliminary study to find problems that must be examined. The author conducted interviews directly with employees of PT S.S in Accounting. This method is used to dig up information about the data collected related to the object of research.

2.2.3. Literature Study, is a method of collecting data which is done by reading books and references from the internet and writing important things related to research.

\subsection{Data Analysis Technique}

In the process of preparing this report, researchers used a qualitative descriptive method. Qualitative descriptive data analysis technique is an analysis technique used to analyze data by describing or describing data that has been collected in a sober manner, without any intention of making generalizations from the results of research. The steps taken in the data analysis technique:

2.3.1. Conduct a preliminary examination to obtain data and information that is general in nature by understanding the company's background.

2.3.2. Conducting direct interviews with leaders and employees at PT. S.S to support the implementation of research.

2.3.3. After the data is collected, it is analyzed in order to find out the accounting treatment of accounts receivable in the context of making the right decision for business development at PT S. S. From this study, the researcher collects data in the form of a list of Business Partner Companies and credit cards for each Business Partner Company.

2.3.4. Penarikan kesimpulan disesuaikan dengan hasil dari proses pengumpulan data.

\section{DISCUSSION}

\subsection{Accounts Receivable Accounting Treatment at PT S.S}

\subsubsection{Measurement and Evaluation of Accounts Receivable}

Measurement of accounts receivables at PT. S.S is seen based on how much the value of the receivables that are expected to be collected in cash from each Business Partner Company. The receivables are obtained from the transfer of capital on credit through business capital financing to the Business Partner Company in accordance with the eligibility and requirements of the company. At PT. S.S Outstanding is the amount of receivables from the principal (ceiling) of each Business Partner Company. The following table lists the receivables from investments that occurred until April 2019. 
Table 3.1 List of Receivables in 2018

\begin{tabular}{|c|c|c|c|c|c|c|c|}
\hline $\begin{array}{r}\text { Num } \\
\text { ber }\end{array}$ & Business Partner Company Name & Effective date & $\begin{array}{l}\text { Due } \\
\text { date }\end{array}$ & $\begin{array}{l}\text { Health } \\
\text { condition }\end{array}$ & $\begin{array}{l}\text { Plafond } \\
\text { (IDR) }\end{array}$ & \begin{tabular}{|l|} 
Invest \\
ment \\
Period \\
\end{tabular} & $\begin{array}{l}\text { Outstanding Until } \\
\text { April } 2019 \text { (IDR) }\end{array}$ \\
\hline 1 & S. S. T & $01 / 01 / 2018$ & $01 / 01 / 2021$ & Healthy & 50.000 .000 & 36 & 29.166 .665 \\
\hline 2 & S. S. T & $01 / 01 / 2018$ & $01 / 01 / 2021$ & Healthy & 50.000 .000 & 36 & 33.500 .988 \\
\hline 3 & W. A & $01 / 18 / 2018$ & $01 / 18 / 2021$ & Healthy & 100.000 .000 & 36 & 58.333 .330 \\
\hline 4 & N.P & $01 / 24 / 2018$ & $01 / 24 / 2021$ & Healthy & 50.000 .000 & 36 & 30.554 .332 \\
\hline 5 & H.P & $01 / 26 / 2018$ & $01 / 26 / 2021$ & Healthy & 100.000 .000 & 36 & 70.139 .774 \\
\hline 6 & H.P & $01 / 26 / 2018$ & $01 / 26 / 2021$ & Healthy & 50.000 .000 & 36 & 38.968 .988 \\
\hline 7 & P. I & $01 / 31 / 2018$ & $01 / 31 / 2021$ & Healthy & 200.000 .000 & 36 & 122.222 .083 \\
\hline 8 & F.S & $01 / 31 / 2018$ & $01 / 31 / 2021$ & Healthy & 200.000 .000 & 36 & 122.222 .216 \\
\hline 9 & O.F & $01 / 31 / 2018$ & $01 / 31 / 2021$ & Healthy & 200.000 .000 & 36 & 116.666 .660 \\
\hline 10 & O.M & $01 / 31 / 2018$ & $01 / 31 / 2021$ & Healthy & 200.000 .000 & 36 & 116.666 .660 \\
\hline 11 & T. P & $02 / 05 / 2018$ & $02 / 05 / 2021$ & Healthy & 200.000 .000 & 36 & 127.943 .994 \\
\hline 12 & L. $\mathrm{H}$ & 02/09/2018 & $02 / 09 / 2021$ & Healthy & 50.000 .000 & 36 & 30.555 .554 \\
\hline 13 & L. M & $02 / 09 / 2018$ & $02 / 09 / 2020$ & Healthy & 27.000 .000 & 24 & 12.815 .150 \\
\hline 14 & P.I & 02/09/2018 & $02 / 09 / 2021$ & Healthy & 150.000 .000 & 36 & 91.666 .662 \\
\hline 15 & M. P & $02 / 19 / 2018$ & $02 / 19 / 2021$ & Healthy & 200.000 .000 & 36 & 127.777 .772 \\
\hline 16 & V.S & $03 / 15 / 2018$ & $03 / 15 / 2023$ & Healthy & 750.000 .000 & 60 & 646.418 .876 \\
\hline 17 & T. I & $03 / 15 / 2018$ & $03 / 15 / 2023$ & Healthy & 350.000 .000 & 60 & 301.642 .870 \\
\hline 18 & S. T & $03 / 26 / 2018$ & $03 / 26 / 2023$ & Healthy & 250.000 .000 & 60 & 215.477 .780 \\
\hline 19 & N.P & $04 / 24 / 2018$ & $04 / 24 / 2022$ & Healthy & 175.000 .000 & 48 & 149.879 .558 \\
\hline 20 & M. G & $04 / 27 / 2018$ & $04 / 27 / 2023$ & Healthy & 150.000 .000 & 60 & 131.491 .093 \\
\hline 21 & A.I & $05 / 14 / 2018$ & $05 / 14 / 2022$ & Healthy & 200.000 .000 & 48 & 174.485 .574 \\
\hline 22 & F.I & $05 / 14 / 2018$ & $05 / 14 / 2023$ & Healthy & 425.000 .000 & 60 & 383.565 .731 \\
\hline 23 & P. T & $06 / 28 / 2018$ & $06 / 28 / 2020$ & Healthy & 70.000 .000 & 24 & 44.477 .852 \\
\hline 24 & L.P & $06 / 28 / 2018$ & $06 / 28 / 2021$ & Healthy & 100.000 .000 & 36 & 91.804 .449 \\
\hline 25 & F.T & $07 / 16 / 2018$ & $07 / 16 / 2023$ & Healthy & 300.000 .000 & 60 & 272.324 .726 \\
\hline 26 & D. P & $08 / 10 / 2018$ & $08 / 10 / 2021$ & Healthy & 250.000 .000 & 37 & 207.638 .523 \\
\hline 27 & D. W & 09/01/2018 & 09/01/2022 & Healthy & 200.000 .000 & 48 & 179.352 .000 \\
\hline 28 & A. I & $08 / 10 / 2018$ & $08 / 10 / 2022$ & Healthy & 150.000 .000 & 49 & 133.140 .027 \\
\hline 29 & J. T & $10 / 15 / 2018$ & $10 / 15 / 2023$ & Healthy & 300.000 .000 & 60 & 283.482 .835 \\
\hline
\end{tabular}




\begin{tabular}{|c|c|c|c|c|c|c|c|}
\hline 30 & Y.P & $10 / 23 / 2018$ & $10 / 23 / 2021$ & Healthy & 200.000 .000 & 36 & 166.666.664 \\
\hline 31 & T. P & $10 / 23 / 2018$ & $10 / 23 / 2021$ & Healthy & 200.000 .000 & 36 & 172.222 .220 \\
\hline 32 & J. A & $10 / 24 / 2018$ & $10 / 24 / 2021$ & Healthy & 200.000 .000 & 36 & 166.666 .664 \\
\hline 33 & P. I & $10 / 25 / 2018$ & $10 / 25 / 2021$ & Healthy & 200.000 .000 & 36 & 166.666 .664 \\
\hline 34 & K. L & $12 / 01 / 2018$ & $12 / 01 / 2021$ & Healthy & 200.000 .000 & 36 & 172.222 .220 \\
\hline 35 & K. M & $12 / 01 / 2018$ & $12 / 01 / 2021$ & Healthy & 125.000 .000 & 36 & 112.124 .822 \\
\hline 36 & K. A & $12 / 01 / 2018$ & $12 / 01 / 2021$ & Healthy & 140.000 .000 & 36 & 120.555 .555 \\
\hline 37 & S. I & $12 / 01 / 2018$ & $12 / 01 / 2021$ & Healthy & 110.000 .000 & 36 & 94.722 .220 \\
\hline 38 & T. T & $12 / 01 / 2018$ & $12 / 01 / 2021$ & Healthy & 750.000 .000 & 36 & 693.524 .664 \\
\hline 39 & J. G & $12 / 01 / 2018$ & $12 / 01 / 2023$ & Healthy & 500.000 .000 & 60 & 475.264 .270 \\
\hline 40 & S. N & $12 / 01 / 2018$ & $12 / 01 / 2021$ & Healthy & 150.000 .000 & 36 & 129.166 .665 \\
\hline 41 & W. I & $11 / 30 / 2018$ & $11 / 30 / 2023$ & Healthy & 1.000 .000 .000 & 60 & 959.697 .351 \\
\hline 42 & L. A & $12 / 14 / 2018$ & $12 / 14 / 2021$ & Healthy & 200.000 .000 & 36 & 177.777 .776 \\
\hline 43 & G. A & $12 / 21 / 2018$ & $12 / 21 / 2021$ & Healthy & 50.000 .000 & 36 & 44.444 .444 \\
\hline 44 & S. A & $12 / 21 / 2018$ & $12 / 1212021$ & Healthy & 100.000 .000 & 36 & 88.888 .888 \\
\hline 45 & M. P & $12 / 20 / 2018$ & $12 / 20 / 2021$ & Healthy & 150.000 .000 & 36 & 133.333 .332 \\
\hline 46 & P.L & $05 / 21 / 2018$ & 05/12/2019 & Healthy & 500.000 .000 & 5 & 500.000 .000 \\
\hline 47 & D. L & $12 / 28 / 2018$ & $12 / 28 / 2021$ & Healthy & 150.000 .000 & 36 & 133.333 .332 \\
\hline 48 & D. $\mathrm{N}$ & $12 / 28 / 2018$ & $12 / 28 / 2021$ & Healthy & 50.000 .000 & 36 & 45.856 .816 \\
\hline 49 & R. O & $12 / 27 / 2018$ & $12 / 27 / 2022$ & Healthy & 198.000 .000 & 48 & 186.355 .245 \\
\hline 50 & A. L & $12 / 27 / 2018$ & $12 / 27 / 2021$ & Healthy & 55.000 .000 & 36 & 50.240 .236 \\
\hline 51 & R. I & $12 / 21 / 2018$ & $12 / 21 / 2023$ & Healthy & 100.000 .000 & 60 & 100.000 .000 \\
\hline 52 & N. N & $04 / 28 / 2018$ & $04 / 28 / 2021$ & $\begin{array}{l}\text { Under } \\
\text { Special } \\
\text { Supervision }\end{array}$ & 100.000 .000 & 36 & 81.461 .413 \\
\hline 53 & J. L & $12 / 18 / 2018$ & $18 / 12 / 2023$ & $\begin{array}{l}\text { Under } \\
\text { Special } \\
\text { Supervision }\end{array}$ & 260.000 .000 & 60 & 254.988 .530 \\
\hline 54 & M. S & $01 / 29 / 2018$ & $01 / 29 / 2020$ & $\begin{array}{l}\text { Under } \\
\text { Special } \\
\text { Supervision }\end{array}$ & 25.000 .000 & 24 & 16.419 .441 \\
\hline 55 & M. T & $02 / 28 / 2018$ & 28/02/2020 & $\begin{array}{l}\text { Under } \\
\text { Special } \\
\text { Supervision }\end{array}$ & 38.000 .000 & 24 & 28.554 .628 \\
\hline 56 & D. L & $01 / 31 / 2018$ & $01 / 31 / 2022$ & $\begin{array}{l}\text { Not } \\
\text { Smooth }\end{array}$ & 95.000 .000 & 48 & 84.821 .905 \\
\hline
\end{tabular}




\begin{tabular}{|c|l|l|l|l|l|l|l|}
\hline 57 & L.P & $02 / 05 / 2018$ & $02 / 05 / 2021$ & Doubtful & 100.000 .000 & 36 & 91.594 .444 \\
\hline 58 & L. P & $02 / 05 / 2018$ & $02 / 05 / 2021$ & Bad Credit & 50.000 .000 & 36 & 48.551 .667 \\
\hline & $\begin{array}{l}\text { Main Receivables Until April } \\
\mathbf{2 0 1 9}\end{array}$ & & & & & $\mathbf{9 . 8 4 0 . 5 0 4 . 7 9 8}$ \\
\hline
\end{tabular}

Source : PT. S.S

Table 3.2 List of Receivables in 2019

\begin{tabular}{|c|c|c|c|c|c|c|c|}
\hline $\begin{array}{r}\text { Num } \\
\text { ber }\end{array}$ & Business Partner Company Name & Effective date & Due date & $\begin{array}{l}\text { Health } \\
\text { condition }\end{array}$ & $\begin{array}{l}\text { Plafond } \\
\text { (IDR) }\end{array}$ & $\begin{array}{l}\text { Invest } \\
\text { ment } \\
\text { Period }\end{array}$ & $\begin{array}{l}\text { Outstanding } \\
\text { Until April } \\
2019 \text { (IDR) }\end{array}$ \\
\hline 1 & P.T & $01 / 11 / 2019$ & $01 / 11 / 2019$ & Healthy & 1.000 .000 .000 & 6 & 1.000 .000 .000 \\
\hline 2 & W.S & $01 / 10 / 2019$ & $01 / 10 / 2022$ & Healthy & 150.000 .000 & 36 & 137.499 .999 \\
\hline 3 & T. L & $01 / 10 / 2019$ & $01 / 10 / 2022$ & Healthy & 150.000 .000 & 36 & 140.762 .209 \\
\hline 4 & L.S & $01 / 14 / 2019$ & $01 / 14 / 2022$ & Healthy & 150.000 .000 & 36 & 137.499 .999 \\
\hline 5 & L.T & $01 / 14 / 2019$ & $01 / 14 / 2022$ & Healthy & 150.000 .000 & 36 & 140.762 .209 \\
\hline 6 & W.S & $01 / 23 / 2019$ & $01 / 23 / 2022$ & Healthy & 100.000 .000 & 36 & 91.666 .666 \\
\hline 7 & H. N & $01 / 28 / 2019$ & $01 / 28 / 2022$ & Healthy & 125.000 .000 & 36 & 114.583 .331 \\
\hline 8 & N.L & $01 / 29 / 2019$ & $01 / 29 / 2022$ & Healthy & 75.000 .000 & 36 & 68.749 .998 \\
\hline 9 & W.L & $01 / 29 / 2019$ & $01 / 29 / 2022$ & Healthy & 200.000 .000 & 36 & 183.333 .332 \\
\hline 10 & L.T & $01 / 31 / 2019$ & $01 / 31 / 2024$ & Healthy & 250.000 .000 & 60 & 249.618 .400 \\
\hline 11 & K.T & $01 / 31 / 2019$ & $01 / 31 / 2022$ & Healthy & 100.000 .000 & 36 & 91.666 .666 \\
\hline 12 & W. L & $02 / 14 / 2019$ & $01 / 14 / 2022$ & Healthy & 200.000 .000 & 36 & 188.888 .888 \\
\hline 13 & W.S & $01 / 15 / 2019$ & $02 / 15 / 2022$ & Healthy & 100.000 .000 & 36 & 94.444 .444 \\
\hline 14 & R.N & $02 / 15 / 2019$ & $02 / 15 / 2022$ & Healthy & 200.000 .000 & 36 & 188.888 .888 \\
\hline 15 & H.L & $02 / 15 / 2019$ & $02 / 15 / 2022$ & Healthy & 150.000 .000 & 36 & 141.666 .666 \\
\hline 16 & W. T & $02 / 19 / 2019$ & $02 / 19 / 2022$ & Healthy & 150.000 .000 & 36 & 141.666 .666 \\
\hline 17 & M.L & $02 / 19 / 2019$ & $02 / 19 / 2022$ & Healthy & 100.000 .000 & 36 & 94.444 .444 \\
\hline 18 & N.T & $02 / 19 / 2019$ & $02 / 19 / 2022$ & Healthy & 50.000 .000 & 36 & 47.222 .222 \\
\hline 19 & M.L & $02 / 22 / 2019$ & $02 / 22 / 2022$ & Healthy & 100.000 .000 & 36 & 94.444 .444 \\
\hline 20 & L.T & $03 / 08 / 2019$ & 03/08/2019 & Healthy & 500.000 .000 & 6 & 500.000 .000 \\
\hline 21 & F.L & $03 / 14 / 2019$ & 03/14/2022 & Healthy & 350.000 .000 & 36 & 342.938 .000 \\
\hline 22 & L.L & $03 / 25 / 2019$ & $03 / 25 / 2023$ & Healthy & 750.000 .000 & 48 & 739.900 .000 \\
\hline 23 & F.S & $03 / 18 / 2019$ & $03 / 18 / 2022$ & Healthy & 70.000 .000 & 36 & 68.587 .000 \\
\hline 24 & D.K & $04 / 26 / 2019$ & $04 / 26 / 2022$ & Healthy & 60.000 .000 & 36 & 60.000 .000 \\
\hline
\end{tabular}




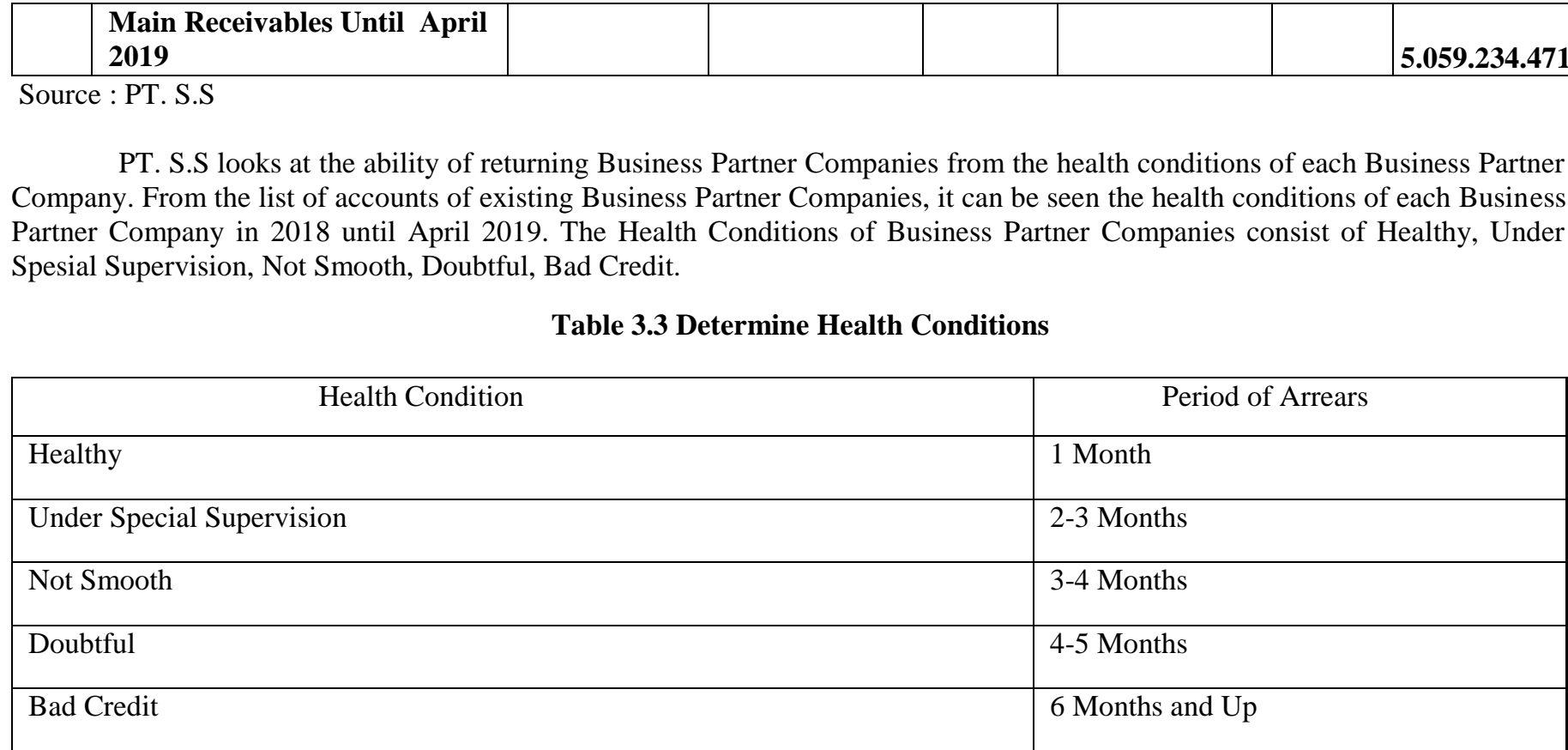

Source: PT. S.S

PT. S.S determines the installment amount of each Business Partner Company based on the determined principal and interest, along with how long the investment period is from financing each Business Partner Company. PT S.S uses credit cards to determine the collection time each month. And for the installment calculation, the company uses the formula in Ms. Excel according to the company's requirements and regulations

\subsubsection{Accounts Receivable Recognition}

From the results of research conducted, PT.S.S conducts their business activities, by providing business financing to Prospective Business Partner Companies. Accounts receivable is recognized at the time of disbursement, or handover of capital to the Business Partner Company beginning with the making of an agreement between the Prospective Business Partner Company and PT. S. S. The existence of an agreement between the Prospective Business Partner Company and PT. S.S, there will be an agreement in the mechanism for financing up to repayment by complying with existing rules.

\subsubsection{Recording Accounts Receivable}

Existing accounting records at PT. S.S uses a computer-based accounting application program. This program is used to input the data of the Business Partner Company, and can update the latest data about the Business Partner Company to the accounting records and financial statements and other functions therein. Companies can also record journals manually.

\subsection{An Accounting Journal To Record The Recognition of Accounts Receivable}

\begin{tabular}{|c|c|c|c|}
\hline Number & Account Name & Debit & Credit \\
\hline & Profit Sharing Investment & Xxx & \\
\hline & Bank/ Cash & & Xxx \\
\hline
\end{tabular}

Source : PT. S.S

\subsection{An Accounting Journal For Recording Receipt of Principal Installments}

\begin{tabular}{|c|c|c|c|}
\hline Number & Account Name & Debit & Credit \\
\hline & Bank/ Cash & Xxx & \\
\hline & Profit Sharing Investment & & Xxx \\
\hline
\end{tabular}

Source : PT. S.S

3.6 An Accounting Journal To Record Interest Receipts

\begin{tabular}{|l|l|l|l|}
\hline Number & Account Name & Debit & Credit \\
\hline
\end{tabular}




\begin{tabular}{|l|l|c|c|}
\hline & Bank/ Cash & Xxx & \\
\hline & Interest Income & & Xxx \\
\hline
\end{tabular}

Source : PT S.S

3.7 An Accounting Journal To Record Adequate Reserves of Impairment (ARoI)

\begin{tabular}{|l|l|c|c|}
\hline Number & Account Name & Debit & Credit \\
\hline & Allowance Fee (ARoI) & Xxx \\
\hline & Allowance Accumulated (ARoI) & Xxx \\
\hline
\end{tabular}

Source : PT. S.S

\subsubsection{Presentation and Disclosure of Accounts Receivable}

Presentation of accounts receivable in the balance sheet at PT. S.S is stated at the net value derived from the profitsharing investment balance, less allowance for profit-sharing investment, the receivables presented in the balance sheet are the amount expected to be collected. But in the presentation of accounts receivable the company uses the term investment profit sharing in accordance with the rules and applicable Operating Standards of the Company. PT. S.S uses a computerized accounting program, which provides financial information needed by management to facilitate company management.

\subsection{Analysis of Accounting Treatment of Accounts Receivable In PT S.S}

After describing the data regarding the accounting treatment of accounts receivable at PT S.S then further analysis is performed to determine the accounting treatment of the company, whether it is in accordance with applicable accounting standards and theories. PT. S.S is a company engaged in the field of financing, or handing over capital to a business partner company for the purpose of developing a business from a Business Partner Company. PT S.S is one of the various types of companies that rely on receivables in running their business. Based on research that has been done it can be said that the accounting treatment of accounts receivable at PT.S.S, in general is in accordance with the theories and accounting standards that apply. This can be seen from the measurement and evaluation of accounts receivable, recognition of accounts receivable, recording of accounts receivable, presentation and disclosure of accounts receivable.

Table 3.8 Comparison Between Accounting Standards and Theory at PT S.S Regarding Accounting Treatment

\begin{tabular}{|c|c|c|c|}
\hline $\begin{array}{c}\text { Based on Financial Accounting Standards and } \\
\text { Theory }\end{array}$ & At PT. S.S & $\begin{array}{l}\text { In Accordance with } \\
\text { Financial Accounting } \\
\text { Standards and } \\
\text { Theories }\end{array}$ & $\begin{array}{l}\text { Not in } \\
\text { Accordance } \\
\text { with Financial } \\
\text { Accounting } \\
\text { Standards and } \\
\text { Theory }\end{array}$ \\
\hline $\begin{array}{l}\text { Measurement and assessment: } \\
\text { Financial assets are measured at fair value for those } \\
\text { recognized. According to Efraim (2012: 130) } \\
\text { Assessment of trade receivables involves } \\
\text { determining the maturity value, the time of } \\
\text { collection, and the uncertainty associated with the } \\
\text { collection. }\end{array}$ & $\begin{array}{l}\text { The Company determines the } \\
\text { amount of the installment based } \\
\text { on the principal and the interest } \\
\text { that has been determined along } \\
\text { with how long the investment } \\
\text { period is from financing the } \\
\text { Business Partner. The company } \\
\text { uses a credit card to determine } \\
\text { the time } \\
\text { collection every month. }\end{array}$ & Corresponding & \\
\hline
\end{tabular}




\begin{tabular}{|c|c|c|}
\hline $\begin{array}{l}\text { Recognition: } \\
\text { the entity recognizes financial assets or financial } \\
\text { liabilities in the statement of financial position, if and } \\
\text { only if, the entity becomes a party to the terms of the } \\
\text { instrument contract. }\end{array}$ & $\begin{array}{l}\text { The Company recognizes } \\
\text { accounts receivable at the time of } \\
\text { disbursement or handover of } \\
\text { capital to the Business Partner } \\
\text { Company beginning with the } \\
\text { binding agreement between the } \\
\text { company and the Business } \\
\text { Partner Company. }\end{array}$ & Corresponding \\
\hline $\begin{array}{l}\text { Presentation and disclosure: Accounts receivable at } \\
\text { presentation in the balance sheet are in the position } \\
\text { of current assets and } \\
\text { using accounts receivable. }\end{array}$ & $\begin{array}{l}\text { The company uses a profit- } \\
\text { sharing investment account in } \\
\text { a long-term investment } \\
\text { position. }\end{array}$ & Corresponding \\
\hline
\end{tabular}

Source: Processed Data 2019

\subsubsection{Measurement and Evaluation of Accounts Receivable}

Measurement of receivables includes when recognized and how much is receivable and must be recorded so that the amount presented shows a fair value. Accounts receivable measurements are made on accounts receivable and notes receivable, because they are often found in a company and usually include large amounts. With the measurement of these receivables, it can be known precisely the fair value of the receivables concerned. In accordance with Statement of Financial Accounting Standards No. 55 (2018) financial assets are measured at fair value for those recognized. In theory, all receivables are measured in an amount that represents the present value of estimated future cash receipts. According to Efraim (2012: 130) Assessment of accounts receivable involves determining the maturity value, the time of collection, and the uncertainty associated with the collection. Accounts receivable are reported at net realizable value, which is the expected value that can be concluded in cash. This amount is equal to the nominal receivables less the estimated amount of uncollectible receivables. Measurement of account receivables at PT. S.S is seen based on how much the value of the receivables that are expected to be collected in cash from each Business Partner Company. The receivables are obtained from the transfer of capital on credit through business capital financing to the Business Partner Company, in accordance with the eligibility and requirements of the company. At PT. S.S, Outstanding is the amount of receivables from the principal (ceiling) of each Company Partner Business. Based on the 2018 accounts receivable table, there are 58 Business Partner Companies. Of the 58 Business Partner Companies there are still bad credit Business Partner Companies. And from the list of accounts receivable in 2019 until April there were 24 Business Partner Companies. From 24 Business Partner Companies, all health conditions are healthy or smooth. For more details can be seen in the percentage table of health conditions below.

Table 3.9 Percentage of Health Conditions in 2018

\begin{tabular}{|l|c|c|}
\hline \multicolumn{1}{|c|}{ Health condition } & Amount & Percentage \\
\hline Healthy & 51 & $51: 58 \times 100=87,94 \%$ \\
\hline Under Special Supervision & 4 & $4: 58 \times 100=6.9 \%$ \\
\hline Not Smooth & 1 & $1: 58 \times 100=1.72 \%$ \\
\hline Doubtful & 1 & $1: 58 \times 100=1.72 \%$ \\
\hline Bad Credit & 1 & $1: 58 \times 100=1.72 \%$ \\
\hline
\end{tabular}

Source: Processed Data 2019

Tabel 3.10 Percentage of Health Conditions in 2019

\begin{tabular}{|l|c|c|}
\hline \multicolumn{1}{|c|}{ Health condition } & Amount & Percentage \\
\hline Healthy & 24 & $24: 24 \times 100=100 \%$ \\
\hline
\end{tabular}




\section{Source: Processed Data 2019}

PT.S.S determines the installment amount of each Business Partner Company based on the determined principal and interest along with how long the investment period is from financing each Business Partner Company. PT. S.S uses credit cards to determine the collection time each month. And for the installment calculation, the company uses the formula in Ms. Excel according to the company's requirements and regulations.

\subsubsection{Recognition of Accounts Receivable}

According to Efraim (2012: 13) recognition of receivables is related to the recording of transactions that give rise to receivables. The amount of receivables recorded is the price of the exchange between the two parties concerned. Exchange rates are the sum of claims to debtors (customers and borrowers). PT SS recognizes accounts receivable at the time of disbursement or handover of capital to the Business Partner Company, which begins with the binding of an agreement with an agreement made in an agreement, regarding the financing mechanism until the repayment is mutually agreed in accordance with existing regulations, and which has been signed by the Business Partner Company, and the company.

\subsubsection{Presentation and Disclosure of Accounts Receivable}

According to Statement of Financial Accounting Standards 1 (2018) paragraph 66, an entity classifies an asset as a current asset if:

1) The entity estimates that it will realize the asset or have the intention to sell or use it, in the normal operating cycle.

2) An entity has assets for trading purposes

3) The entity estimates that the assets will be realized within 12 months after the reporting period

4) Assets are cash or cash equivalents, unless the assets are restricted by exchange or their use to settle liabilities for at least 12 months after the reporting period. According to Statement of Financial Accounting Standards 60 (2018) paragraph 07, it states that an entity discloses information that enables users of financial statements to evaluate the significance of financial instruments for financial position and performance. PT.S.S uses a computerized accounting system in the form of the Simvati program, which provides financial information needed by management to facilitate company management. A computer program is an information system used by companies to manage company activities to the presentation of company financial information. Presentation of accounts receivable at PT. S.S uses a profit-sharing investment account in a long-term investment position.

\subsubsection{Decision Making by the Management}

For decision making, which is the basis of the management in making decisions regarding the provision of receivables, namely the credit cards of each Company Business Partner. From the credit card can be seen receivable reports for each Business Partner Company, whether the Business Partner Company has a problem or not. The management of PT.S.S makes steps in making decisions for the problematic Business Partner Companies, namely:

3.2.4.1 Handling of Business Partner Companies with problems are submitted to the remedial department

3.2.4.2 The remedial section makes a mapping of the troubled Business Partner Company, this mapping contains the name of the Business Partner Company, and the steps to settle it are in the form of voluntary collateral sales, or must be auctioned or debt restructuring can be carried out with notes that the Business Partner Company is still capable of paying to PT.SS

3.2.4.3 After the mapping is done the paramedics must make a report to management for approval or step by step.

Decisions taken by management or directors for a troubled Business Partner Company, which is in accordance with the initial agreement that has been agreed in the notarial financing agreement. If the Business Partner Company does not fulfill the obligations, conditions and restrictions specified in the financing agreement, the company has the right to provide the first, second and third or last warning letter within the period specified by the company, followed by seizure execution of guarantee.

\section{Conclusion}

Based on the results of research at PT S.S, it can be concluded that:

1. The measurement of trade receivables at PT.SS can be seen from the value of the expected receivables that can be collected from each of the Business Partner Companies, and in the valuation of the company determines the amount of installments of each Business Partner Company based on the loan principal, and the interest that has been determined along with how long the investment period of financing each Business Partner Company.

2. PT S.S determines the installment amount of each Business Partner Company based on the loan principal, and the interest that has been determined along with how long the investment period is from financing each Business Partner Company. The company uses the backup method or allowance method to assess the net amount of accounts receivable or investment profit sharing which can be realized in cash.

3. Recognition of accounts receivable at PT.S.S is recognized at the time of disbursement or delivery of venture capital to 
the Business Partner Company, where the company will record in the bookkeeping as the initial investment which is then expected to benefit from the investment.

4. Presentation and disclosure of accounts receivable at PT. S.S uses a computer-based application program. The company uses a profit-sharing investment account presented in the balance sheet less the accumulated allowance for possible losses.

5. Based on the results of the analysis conducted at PT. S.S can be concluded that the accounting treatment of accounts receivable is almost in accordance with applicable accounting standards. But based on the health condition of the Business Partner Company data, there are still Business Partner Companies with problems (doubtful and bad credit). Then the management needs to make a decision for the problematic Business Partner Company

\section{REFERENCES}

Arikunto, S. 2010. Research Procedure A Practical Approach, Rineka Cipta. Jakarta

Efraim, 2012. Intermediate Financial Accounting 1 IFRS Perspective. Publisher: UPP STIM YKPN. Yogyakarta

Harahap Sofyan Syafri, 2011. Revised Edition of Theory of Accounting, Rajawali Pers. Jakarta

Hery, 2016. Asset, Debt and Capital Accounting. Publisher: Gava Media. Yogyakarta

Ikatan Akuntan Indonesia, 2018. Presentation of Financial Statements 12018, Jakarta:IAI Ikatan Akuntan Indonesia, 2018.

Ikatan Akuntan Indonesia, 2018. Statement of Financial Accounting Standards 60 2018. Jakarta:IAI

Mukhtar, 2013. Practical Methods of Qualitative Descriptive Research, GP Press Group. Jakarta

Statement of Financial Accounting Standards 55 2018. Jakarta:IAI

Sugiyono, 2014. Educational Research Methods With Quantitative, Qualitative, and R\&D Approaches Bandung: Alfabeta. 